OPEN ACCESS

Edited by:

Carlos Pelleschi Taborda, Universidade de São Paulo, Brazil

Reviewed by:

Guilherme Lanzi Sassaki, Universidade Federal do Paraná,

Brazil

Vania Aparecida Vicente Aparecida Vicente,

Universidade Federal do Paraná

Brazil

*Correspondence: Lucimar F. Kneipp

lucimar@ioc.fiocruz.br André L. S. Santos andre@micro.ufrj.br

Specialty section: This article was submitted to Fungi and Their Interactions, a section of the journal

Frontiers in Microbiology

Received: 12 March 2018 Accepted: 06 June 2018

Published: 29 June 2018

Citation:

Palmeira VF, Goulart FRV, Granato MQ, Alviano DS, Alviano CS, Kneipp LF and Santos ALS (2018) Fonsecaea pedrosoi Sclerotic Cells: Secretion of Aspartic-Type Peptidase and Susceptibility to Peptidase Inhibitors. Front. Microbiol. 9:1383. doi: 10.3389/fmicb.2018.01383

\section{Fonsecaea pedrosoi Sclerotic Cells: Secretion of Aspartic-Type Peptidase and Susceptibility to Peptidase Inhibitors}

\author{
Vanila F. Palmeira ${ }^{1,2}$, Fatima R. V. Goulart'2, Marcela Q. Granato ${ }^{3}$, Daniela S. Alviano², \\ Celuta S. Alviano ${ }^{2}$, Lucimar F. Kneipp ${ }^{3 *}$ and André L. S. Santos ${ }^{1,4 *}$
}

\begin{abstract}
'Laboratório de Estudos Avançados de Microrganismos Emergentes e Resistentes, Departamento de Microbiologia Geral, Instituto de Microbiologia Paulo de Góes, Universidade Federal do Rio de Janeiro, Rio de Janeiro, Brazil, ${ }^{2}$ Laboratório de Estrutura de Microrganismos, Departamento de Microbiologia Geral, Instituto de Microbiologia Paulo de Góes, Universidade Federal do Rio de Janeiro, Rio de Janeiro, Brazil, ${ }^{3}$ Laboratório de Taxonomia, Bioquímica e Bioprospecção de Fungos, Instituto Oswaldo Cruz, Fundação Oswaldo Cruz, Rio de Janeiro, Brazil, ${ }^{4}$ Programa de Pós-Graduação em Bioquímica, Instituto de Química, Universidade Federal do Rio de Janeiro, Rio de Janeiro, Brazil
\end{abstract}

Fonsecaea pedrosoi is a dematiaceous fungus and the main causative agent of chromoblastomycosis that is a chronic disease usually affecting the human skin and subcutaneous tissues, which causes deformations and incapacities, being frequently refractory to available therapies. A typical globe-shaped, multiseptated and pigmented cells, known as sclerotic cells, are found in the lesions of infected individuals. In the present work, we have investigated the production of aspartic-type peptidase in F. pedrosoi sclerotic cells as well as the effect of peptidase inhibitors (PIs) on its enzymatic activity and viability. Our data showed that sclerotic cells are able to secrete pepstatin A-sensible aspartic peptidase when grown under chemically defined conditions. In addition, aspartic Pls (ritonavir, nelfinavir, indinavir, and saquinavir), which are clinically used in the HIV chemotherapy, significantly decreased the fungal peptidase activity, varying from 55 to 99\%. Moreover, sclerotic cell-derived aspartic peptidase hydrolyzed human albumin, an important serum protein, as well as laminin, an extracellular matrix component, but not immunoglobulin $G$ and fibronectin. It is well-known that aspartic peptidases play important physiological roles in fungal cells. With this task in mind, the effect of pepstatin A, a classical aspartic peptidase inhibitor, on the F. pedrosoi proliferation was evaluated. Pepstatin A inhibited the fungal viability in both cellular density- and drug-concentration manners. Moreover, HIVPls at $10 \mu \mathrm{M}$ powerfully inhibited the viability (>65\%) of $F$. pedrosoi sclerotic cells. The detection of aspartic peptidase produced by sclerotic cells, the parasitic form of F. pedrosoi, may contribute to reveal new virulence markers and potential targets for chromoblastomycosis therapy.

Keywords: Fonsecaea pedrosoi, chromoblastomycosis, aspartic peptidase, peptidase inhibitors, antifungal drug 


\section{INTRODUCTION}

Fonsecaea pedrosoi is a melanized saprophytic filamentous fungus able to cause a chronic, progressive and granulomatous skin and/or subcutaneous tissue infections, named chromoblastomycosis, which occur most frequently in humid tropical and subtropical regions of America, Asia and Africa (Santos et al., 2007; Queiroz-Telles et al., 2017). This dimorphic fungus produce different morphotypes including conidia (reproduction structures) and mycelia (filamentous forms), both are usually found in its saprophytic lifestyle, as well as sclerotic cells (synonymous with muriform or medlar bodies), which are the parasitic forms observed in the infected tissues (Rippon, 1988). These brownish-yellow fungal cells with thick-pigmented walls are a hallmark in the histopathological diagnosis of chromoblastomycosis (Krzyściak et al., 2014). The morphology of sclerotic cell is well-known, but its physiology remains poorly studied, mainly because this tissue form is very hard to be induced in vitro and is not usually obtained in high quantities in its disarticulated state (Santos et al., 2007). Even though, there are several reports showing different procedures to induce in vitro sclerotic cell formation from chromoblastomycosis fungi, such as $\mathrm{pH}$ reduction, manganese deprivation, calcium or propranolol supplementation and natural culture medium formulated from tree fruits (Alviano et al., 1992; Mendoza et al., 1993; Silva et al., 2002, 2008). Studies conducted by our group revealed that sclerotic cells obtained in vitro were similar to those observed in vivo. The cellular morphology, ultrastructure, as well as the antigenic cross-reactivity between in vivo and in vitro sclerotic cells confirmed their similarity, showing that the latter can be used in experiments aiming to understand the physiopathology of chromoblastomycosis fungi (Silva et al., 2002).

In the past, sclerotic cells were mainly known as resistant forms able to survive inside the host tissues. However, several studies have shown that sclerotic cells are active parasitic forms involved directly with F. pedrosoi pathogenicity (Silva et al., 2002; Alviano et al., 2004; Siqueira et al., 2017). In addition, sclerotic cells are extremely resistant to immune system attack. Dong et al. (2014) reported a chitin-like component, expressed on the surface of $F$. pedrosoi sclerotic cells, able to inhibit dectin-1-mediated murine Th17 development by masking fungal $\beta$-glucans, which consequently blocks the recruitment of neutrophils to the infectious foci. Recently, chromoblastomycosis murine model studies revealed that only sclerotic cells depend on dectin-1 recognition to be internalized, suggesting different $F$. pedrosoi-host interaction strategies related to fungal morphotypes (Siqueira et al., 2017). Furthermore, those authors also reported that $F$. pedrosoi sclerotic cells are the ones responsible for the intense inflammatory reaction, correlated with the fungus persistence in the host, which leads to the chronic phase of chromoblastomycosis. These reasons could explain the difficulty in treating this chronic disease, even more after considering the fact that highly melanized sclerotic cells make the fungi much more resistant to different classes of antifungal drugs (Revankar and Sutton, 2010; Queiroz-Telles et al., 2017).

The chromoblastomycosis pathogenicity mechanisms are not well established. However, in recent years, our research group has described some enzymes involved in the physiopathology of chromoblastomycosis fungi, including peptidases (Kneipp et al., 2003, 2004, 2012; Palmeira et al., 2006a,b, 2008, 2017; Granato et al., 2015). It is known that proteolytic enzymes participate in infectious processes caused by a number of human pathogenic fungi, being main actors in several aspects of fungi-host interplays such as adhesion, invasion, nutrition, escape, proliferation, and differentiation (Monod et al., 2002; Yike, 2011; Puri et al., 2012). Over the last years, we identified and characterized the proteolytic activity secreted by F. pedrosoi conidia and mycelia which are correlated to important events such as cellular differentiation, growth and interaction with host cells (Palmeira et al., 2006a,b, $2008,2017)$. Several studies have proposed that fungal peptidases are potential targets to develop new antifungal drugs (Pozio and Morales, 2005; Santos, 2010; Santos and Braga-Silva, 2013; Santos et al., 2013). Corroborating this statement, HIV aspartic peptidase inhibitors (HIV-PIs) are able to block the hydrolytic activity of aspartic peptidases released by F. pedroso $i$ conidial and mycelial forms as well as their in vitro growth (Palmeira et al., 2006b, 2008, 2017). Furthermore, HIV-PIs treatment restrained the conidia-into-mycelia differentiation as well as reduced their adhesion to mammalian cells (Palmeira et al., 2008).

For all the reasons elucidated above, in the present work, we have investigated the capability of $F$. pedrosoi sclerotic cells in releasing aspartic-type peptidase into the extracellular surrounding. Also, the effects of aspartic PIs were evaluated on fungal enzymatic activity and viability.

\section{MATERIALS AND METHODS}

\section{Chemicals}

Saquinavir and nelfinavir were obtained from Hoffmann-La Roche AG (Grenzach-Wyhlen, Germany), indinavir from Merck Sharp \& Dohme GmbH (Haar, Germany) and ritonavir from Abbot Park (Illinois, United States). The HIV-PIs were dissolved in absolute methanol to obtain a final concentration of $20 \mathrm{mM}$ and stored at $-20^{\circ} \mathrm{C}$ before use. Human serum albumin (HSA), bovine serum albumin (BSA), immunoglobulin G (IgG), laminin (LAM), fibronectin (FBN), trans-epoxysuccinyl L-leucylamido(4-guanidino) butane (E-64), phenylmethylsulfonyl fluoride (PMSF), pepstatin A and 1,10-phenanthroline were purchased from Sigma Chemical Co. (St. Louis, United States). Media constituents, reagents used in electrophoresis and buffer components were purchased from Amersham Life Science (Little Chalfont, United Kingdom). All other reagents were of analytical grade.

\section{Fungal Strain and Growth Conditions}

Fonsecaea pedrosoi (ATCC 46428, formerly 5VLP) isolated from a human patient with chromoblastomycosis (Oliveira et al., 1973) was used in all parts of the present work. Stock cultures were maintained on Sabouraud dextrose agar under mineral oil. The fungal cultures were kept at $4^{\circ} \mathrm{C}$ and transfers were made every 6 months. For sclerotic cell formation, cultures were incubated for 30 days under constant agitation $(200 \mathrm{rpm})$ at $37^{\circ} \mathrm{C}$ in Erlenmeyer flask containing $100 \mathrm{~mL}$ of Butterfield's chemically 
defined medium ( $\mathrm{pH}$ 2.5): $5 \mathrm{~mL}$ glycerol, $0.1 \mathrm{~g} \mathrm{MgSO}_{4}, 1.8 \mathrm{~g}$ $\mathrm{KH}_{2} \mathrm{PO}_{4}, 1.5 \mathrm{~g} \mathrm{NH}_{4} \mathrm{NO}_{3}, 5 \mathrm{mg}$ biotin and $0.1 \mathrm{mg}$ thiamine$\mathrm{HCl}$ per liter (Alviano et al., 1992). For all the experiments, sclerotic cells were washed three times in saline $(0.85 \% \mathrm{NaCl})$ and the number of cells was estimated by counting in a Neubauer chamber.

\section{Cell-Free Culture Supernatant and Protein Content}

The sclerotic cultures were centrifuged $\left(4000 \times g, 10 \mathrm{~min}, 4^{\circ} \mathrm{C}\right)$ and the supernatants were filtered in a $0.22-\mu \mathrm{m}$ membrane (Millipore). The cell-free culture supernatants were 100-fold concentrated in a 10,000 molecular weight cut-off Amicon micropartition system (Beverly, MA, United States) (Palmeira et al., 2008). Protein concentration was detected by the method described by Lowry et al. (1951), using BSA as standard.

\section{Proteolytic Activity Measurements}

Extracellular proteolytic activity was measured spectrophotometrically according to the method described by BurokerKilgore and Wang (1993). Briefly, $20 \mu \mathrm{L}$ of concentrated supernatant (equivalent to $10 \mu \mathrm{g}$ of protein) were incubated in the absence (control) or in the presence of BSA substrate $(0.5 \mathrm{mg} / \mathrm{mL})$. Alternatively, the concentrated supernatant was added to different buffers, such as $10 \mathrm{mM}$ sodium citrate $(\mathrm{pH}$ 2.0 - 4.0), $50 \mathrm{mM}$ phosphate buffer ( $\mathrm{pH} 5.0$ - 8.0) or $20 \mathrm{mM}$ glycine- $\mathrm{NaOH}(\mathrm{pH} 9.0$ - 10.0) to determine the optimum enzyme $\mathrm{pH}$. In addition, the supernatant was incubated in the presence of classical PIs (10 mM PMSF, $10 \mu \mathrm{M}$ E-64, $10 \mathrm{mM}$ 1,10-phenanthroline and $10 \mu \mathrm{M}$ pepstatin A) and HIV-PIs at $100 \mu \mathrm{M}$ (saquinavir, indinavir, ritonavir and nelfinavir) in order to distinguish the peptidase enzyme class. After $1 \mathrm{~h}$ at $37^{\circ} \mathrm{C}, 100 \mu \mathrm{L}$ of reaction mixtures were transferred to wells on a microtiter plate containing $50 \mu \mathrm{L}$ of water and $100 \mu \mathrm{L}$ of a Coomassie solution $(0.025 \%$ Coomassie brilliant blue G-250, $11.75 \%$ ethanol and $21.25 \%$ phosphoric acid). After $10 \mathrm{~min}$, to allow dye binding, the plate was read on a Molecular Devices Thermomax microplate reader at an absorbance of $595 \mathrm{~nm}$. One unit of proteolytic activity was defined as the amount of enzyme that caused an increase of 0.001 in absorbance unit, under standard assay conditions (Palmeira et al., 2008).

\section{Soluble Proteins' Cleavage Profiles}

In this set of experiments, the concentrated supernatant $(20 \mu \mathrm{L}$, which is equivalent to $10 \mu \mathrm{g}$ of protein) obtained from sclerotic cells were incubated for $16 \mathrm{~h}$ at $37^{\circ} \mathrm{C}$ in the presence of the following proteinaceous substrates: BSA, HSA, FBN, LAM, and IgG. These proteins were diluted in $10 \mathrm{mM}$ sodium citrate $(\mathrm{pH}$ 4.0) to obtain a final concentration of $5 \mu \mathrm{g} / \mathrm{mL}$. Then, the reaction mixtures were added to $10 \mu \mathrm{L}$ SDS-PAGE sample buffer supplemented with $5 \% \beta$-mercaptoethanol, and boiled at $100^{\circ} \mathrm{C}$ for $5 \mathrm{~min}$. The degradation protein profiles were analyzed using $10 \%$ SDS-PAGE. Electrophoresis was carried out at $4^{\circ} \mathrm{C}$, at $120 \mathrm{~V}$. Then, gels were stained with silver nitrate to evidence the protein cleavage profiles. Controls were made by replacing concentrated culture supernatants with the same volume of citrate buffer (Palmeira et al., 2006a).

\section{Influence of Aspartic PIs on F. pedrosoi Development}

To test the possible involvement of aspartic peptidases on F. pedrosoi viability, different cellular densities $\left(10^{2}-10^{6}\right.$ sclerotic cells) were resuspended in Butterfield's chemically defined broth medium. Aliquots $(100 \mu \mathrm{L})$ of this suspension were added to sterile microcentrifuge tubes and then complemented with $10 \mu \mathrm{M}$ of pepstatin A. A control was made by replacing the $\mathrm{PI}$ with phosphate-buffered saline (PBS, $\mathrm{pH} 7.2$ ). Alternatively, $10^{5}$ sclerotic cells were also treated with different pepstatin A concentrations $(0.1,1,5,10$, and $20 \mu \mathrm{M})$ or HIV-PIs at $10 \mu \mathrm{M}$. The mixtures were incubated for $20 \mathrm{~h}$ at $37^{\circ} \mathrm{C}$ without agitation. The sclerotic cells were then harvested by centrifugation, washed twice with PBS and re-inoculated into solid medium without drugs, in order to measure the colony-forming units (CFU) (Palmeira et al., 2008). Methanol, the diluent of PIs, was also tested.

\section{Statistical Analysis}

All the experiments were repeated at least three times. All the systems were performed in triplicate, and representative images of these experiments are shown. The data was analyzed statistically by Student's $t$-test using EPI-INFO 6.04 (Database and Statistics Program for Public Health) computer software. $P$-values of 0.05 or less were considered statistically significant.

\section{RESULTS AND DISCUSSION}

\section{Fonsecaea pedrosoi Sclerotic Cells Secrete Acidic Peptidase}

We have shown that chromoblastomycosis fungi secrete distinct peptidases and that these enzymatic profiles are closely related with fungal morphology and cultivation conditions (Palmeira et al., 2006a,b, 2008, 2017; Granato et al., 2015). Studies have reported that cell shape modifications are strategies used by different fungi to survive in the environment and inside the host (Wang and Lin, 2012). Considering that F. pedrosoi morphological transition from conidia/mycelia to sclerotic cells is an essential step to the establishment of chromoblastomycosis, the extracellular proteolytic profile of sclerotic cells was analyzed in this study. Thus, after the growth of $F$. pedrosoi sclerotic cells under chemically defined conditions (Figure 1A), the culture supernatant was incubated with soluble BSA, at different pHs (varying from 2.0 to 10.0), in order to evidence its possible cleavage by any released fungal peptidase (Figure 1B). The BSA degradation was observed only in acidic $\mathrm{pH}$ values, reaching a maximum hydrolytic activity at $\mathrm{pH} 4.0$ (Figure 1B), which was clearly evidenced by the generation of polypeptide fragments with low molecular masses (Figure 1C). In the current study, we showed for the first time that sclerotic cells were able to produce an extracellular peptidase that was active at extremely acidic $\mathrm{pH}$, as also described for 


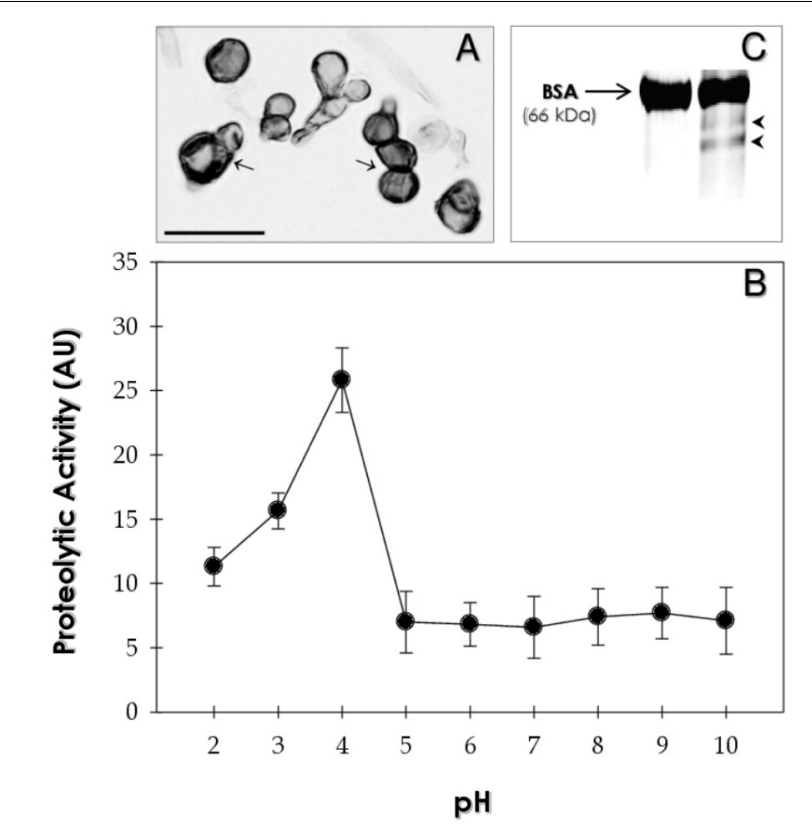

FIGURE 1 | Peptidase activity released by F. pedrosoi sclerotic cells. (A) Optical microscopy showing the sclerotic cells obtained after in vitro growth in Butterfield's chemically defined medium (pH 2.5). Dark-brown, thick-walled and spherical fungal cells exhibiting typical planate division can be observed (arrows). The image was captured by Zeiss Axioplan 2 microscope using an AxioCam camera. Bar: $20 \mu \mathrm{m}$. (B) The influence of $\mathrm{pH}$ on the peptidase activity released by sclerotic cells was evaluated. Fungal concentrated supernatant was incubated with the substrate (BSA) in different buffers: $10 \mathrm{mM}$ sodium citrate $(\mathrm{pH} 2.0-4.0), 50 \mathrm{mM}$ phosphate buffer $(\mathrm{pH}$ $5.0-8.0$ ) or $20 \mathrm{mM}$ glycine- $\mathrm{NaOH}(\mathrm{pH} 9.0-10.0)$ for $1 \mathrm{~h}$ at $37^{\circ} \mathrm{C}$. The reaction mixtures were measured at $595 \mathrm{~nm}$ and the proteolytic activity expressed in arbitrary units (AU), which was defined as the amount of enzyme that caused an increase of 0.001 in absorbance. (C) Substrate BSA was incubated for $1 \mathrm{~h}$ at $37^{\circ} \mathrm{C}$ in the absence (first slot) and presence of concentrated supernatant (second slot). Subsequently, both systems were supplemented with $10 \mathrm{mM}$ sodium citrate $\mathrm{pH} 4.0$ and subjected to SDS-PAGE. The arrow (on the left) shows the molecular mass of intact BSA. The arrowheads on the right indicate the fragmentation of BSA after proteolysis.

conidial and mycelial forms of this fungus (Palmeira et al., 2006b, 2008), and for another chromoblastomycosis agent, Phialophora verrucosa (Granato et al., 2015). Coincidentally, filamentous forms of $F$. pedrosoi convert themselves into sclerotic cells in in vitro when incubated at acidic $\mathrm{pH}$ (2.5) (Mendoza et al., 1993). In addition, acidic peptidase produced by $F$. pedrosoi could facilitate its survival in acidic conditions usually detected inside the phagocytic cells (Palmeira et al., 2006b). Consequently, the differential pattern of peptidase expression may be essential for fungal adaptation to various environments, including host tissues (Naglik et al., 2003; Santos et al., 2007).

Recently, F. pedrosoi genome was entirely sequenced (Teixeira et al., 2017), which permits the beginning of the genomic analysis in order to better understand the functional organization of the genes and to decipher their potential roles. Fonsecaea species and other black fungi belonging to the bantiana-clade were predicted to produce a wide repertoire of different endo- and exopeptidases (Vicente et al., 2017). Peptidase-encoding genes were predicted using the MEROPS database, which revealed the abundance of three major classes: serine (S), metallo (M) and cysteine (C) peptidases. Members of Herpotrichiellaceae, which include Fonsecaea, presented specific and significant number of S09 (prolyl oligopeptidase), S33 (prolyl aminopeptidase) and M38 (isoaspartic dipeptidase) families (Teixeira et al., 2017). In that study, it was also detected an expansion of M38 proteins, which may be associated with $\beta$-aspartic dipeptidase that act in the release of iso-aspartate residues from peptides (Teixeira et al., 2017). Caspases, which are cysteine dependent asparticspecific peptidase playing essential roles in programmed cell death and inflammation, occur in the Fonsecaea core genome (Madeo et al., 2002; Douglas et al., 2015; Vicente et al., 2017).

\section{The Acidic Peptidase Released by F. pedrosoi Sclerotic Cells Is an Aspartic-Type Peptidase}

The effect of classic PIs on the acidic peptidase released by F. pedrosoi sclerotic cells was evaluated. Pepstatin A, a classical aspartic PI, was able to drastically block the fungal released proteolytic activity by around 90\% (Figure 2). In addition, 1,10-phenanthroline (a metallo-PI/chelating agent) partially reduced the enzymatic activity by approximately 45\% (Figure 2). Conversely, sclerotic cells acidic peptidase activity was not significantly inhibited by PMSF (a serine PI) or E-64 (a cysteine PI). Taking into consideration the extremely acidic $\mathrm{pH}$ for peptidase activity as well as its inhibitory profile, the peptidase released by F. pedrosoi sclerotic cells can be classified as an aspartic-type peptidase. Our results corroborate previous in silico studies that predicted the presence of aspartic peptidase-encoding genes in F. pedroso $i$ genome (Teixeira et al., 2017; Vicente et al., 2017). Aspartic peptidases are characterized in different ways, according to their catalytic properties, cellular localization and pepstatin A inhibition, for example (Santos et al., 2013). Pepstatin A was also able to block the aspartic peptidase activities produced by other pathogenic filamentous fungi, including Sporothrix schenckii, Aspergillus fumigatus, Paracoccidioides brasiliensis, Pseudallescheria boydii, Scedosporium aurantiacum, and Trichosporon asahii (Tsuboi et al., 1988; Vickers et al., 2007; Tacco et al., 2009; Silva et al., 2012; Han et al., 2017; Valle et al., 2017). In order to confirm our results, the effects of four different HIV-PIs, which are capable of blocking the proteolytic enzymes belonging to the aspartic peptidase class, were tested on the fungal peptidase at a concentration of $100 \mu \mathrm{M}$. The HIV-PIs restrained the aspartic proteolytic activity from $F$. pedrosoi sclerotic cells as follows: saquinavir was the most effective, inhibiting the enzymatic activity in 99\%, while indinavir, nelfinavir and ritonavir reduced the peptidase activity in $85,70 \%$ and 55\%, respectively (Figure 2).

Aspartic-type peptidases produced by several fungi were also inhibited by HIV-PIs (Santos et al., 2013). For instance, 


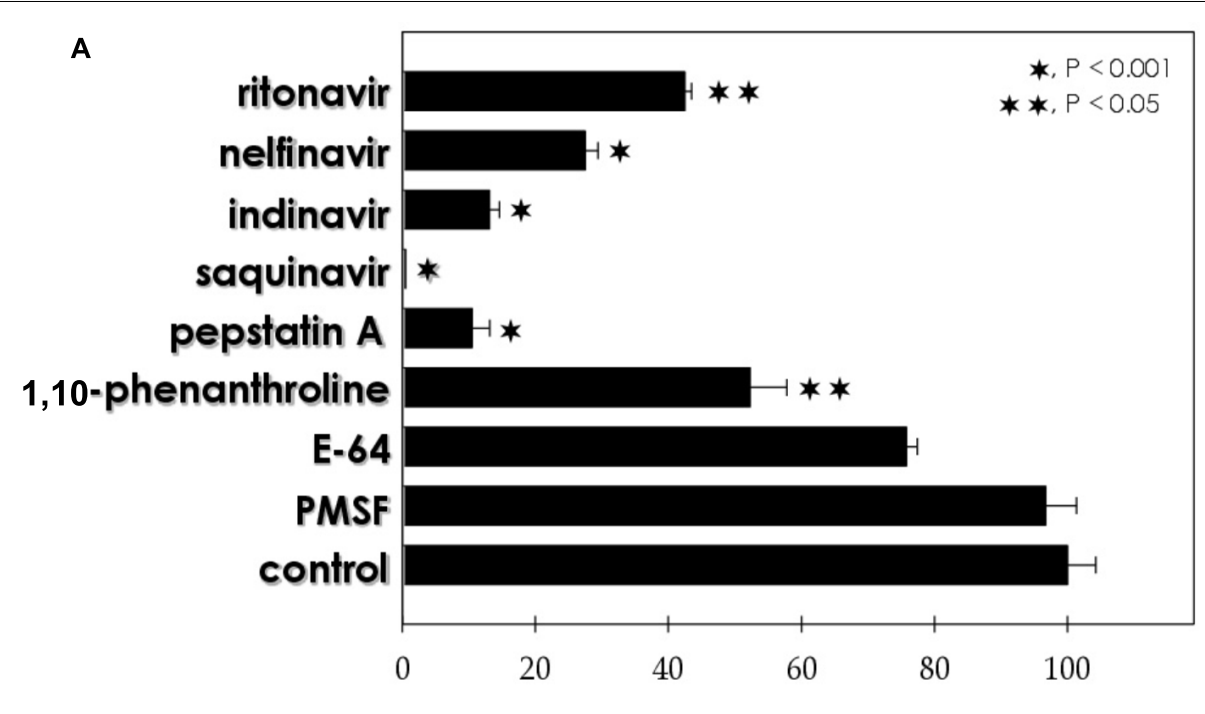

\% Proteolytic Activity

B

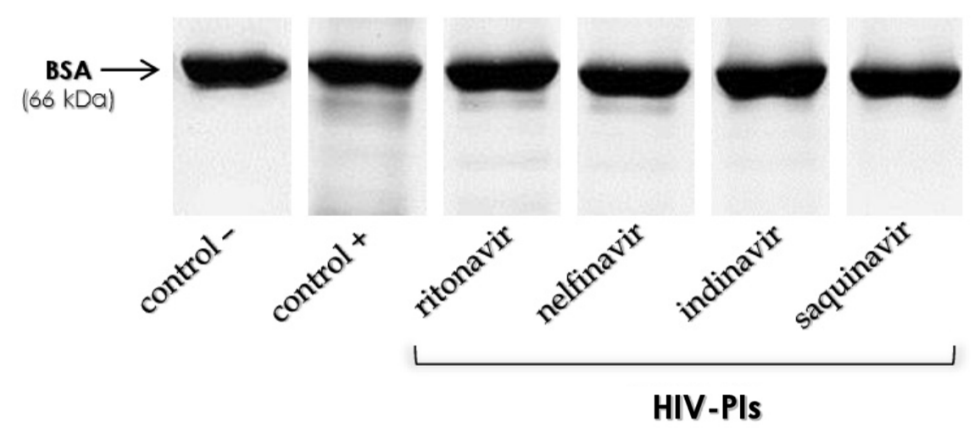

FIGURE 2 | Effect of proteolytic inhibitors on the peptidase activity released by sclerotic cells. (A) Concentrated supernatant was incubated for $1 \mathrm{~h}$ at $37^{\circ} \mathrm{C}$ in $10 \mathrm{mM}$ sodium citrate buffer, $\mathrm{pH}$ 4.0, and BSA, in the absence (control) or presence of classical proteolytic inhibitors, such as $10 \mu \mathrm{M}$ pepstatin, $10 \mathrm{mM}$ 1,10-phenanthroline, $10 \mu \mathrm{M} \mathrm{E}-64$ or $10 \mathrm{mM}$ PMSF; and $100 \mu \mathrm{M}$ of the following HIV-PIs: ritonavir, nelfinavir, indinavir, or saquinavir. BSA supplemented exclusively with buffer was used as control. Peptidase activity was determined as described by Buroker-Kilgore and Wang (1993). The symbols denote the system treated with inhibitors that had a substrate hydrolysis rate significantly different from control ( ${ }^{*} P<0.001$ and ${ }^{* *} P<0.05$; Student's $t$-test). The peptidase activity was converted to percentage considering the control value as $100 \%$. (B) Representative gels showing the intact BSA molecule diluted in sodium citrate buffer, pH 4.0 (control -), BSA degraded by the extracellular peptidase secreted by sclerotic cells (control + ) and the BSA cleavage inhibition by HIV-PIs at $100 \mu \mathrm{M}$.

amprenavir was the most potent inhibitor of the secreted aspartic peptidases (Sap), the principal virulence factor produced by Candida albicans (Braga-Silva et al., 2010). This inhibitor reduced the activity of Sap 2 by around $90 \%$ at $100 \mu \mathrm{M}$. Recently, Valle et al. (2017) reported that saquinavir and atazanavir were able to impair the aspartic peptidase activity secreted by T. asahii by around 50 and $70 \%$, respectively. The HIV-PIs ritonavir, indinavir and nelfinavir also inhibited the aspartic peptidase activity produced by both conidial and mycelial forms of F. pedrosoi (Palmeira et al., 2006b, 2008), while saquinavir did not significantly alter the mycelial aspartic proteolytic activity (Palmeira et al., 2006b). These data indicated that $F$. pedrosoi morphotypes secrete distinct aspartic peptidase activities, which respond differently to the HIV-PIs tested (Table 1). Studies have reported the differential expression of aspartic peptidases during the fungal morphogenesis and that aspartic PIs might control this essential phenomenon to the establishment of fungal infection (Braga-Silva et al., 2010; Santos et al., 2013).

\section{Cleavage of Different Proteinaceous Substrates}

To provide more information about the aspartic peptidase secreted by $F$. pedrosoi sclerotic cells, we tested its capability of cleaving key host proteinaceous substrates, including serum proteins (HSA and IgG) and extracellular matrix components (LAM and FBN). The results revealed that the aspartic peptidase of $F$. pedrosoi sclerotic cells was able to hydrolyze HSA and LAM, yielding low molecular mass polypeptides, while FBN and IgG were not degraded under the employed experimental conditions (Figure 3). Pepstatin A blocked the cleavage of both HSA and LAM (data not shown). The protein cleavage 
TABLE 1 | Overview of the action of aspartic peptidase inhibitors on the peptidase activity and viability of F. pedrosoi morphotypes.

\begin{tabular}{|c|c|c|c|c|c|c|c|c|c|c|c|c|}
\hline \multirow{2}{*}{$\begin{array}{l}\text { Fungal } \\
\text { Form }\end{array}$} & \multicolumn{2}{|c|}{ Secreted aspartic peptidase } & \multicolumn{5}{|c|}{$\%$ of peptidase inhibition } & \multicolumn{5}{|c|}{$\%$ of growth inhibition* } \\
\hline & Optimum pH & $\begin{array}{c}\text { Enzymatic } \\
\text { activity (AU) }\end{array}$ & PEP & IDV & RTV & NFV & SQV & PEP & IDV & RTV & NFV & SQV \\
\hline Conidia & 4.0 & $42.7 \pm 6.5$ & 95 & 71 & 58 & 93 & 70 & 99 & 20 & 25 & 99 & 90 \\
\hline Mycelia & 2.0 & $113.5 \pm 8.1$ & 95 & 97 & 97 & 90 & 28 & ND & $N D$ & ND & ND & ND \\
\hline Sclerotic & 4.0 & $26.0 \pm 2.3$ & 90 & 85 & 55 & 70 & 99 & 80 & 91 & 88 & 95 & 67 \\
\hline
\end{tabular}

The proteolytic activity and fungal growth inhibition were determined as detailed in the current material and methods and in the previous publications (Palmeira et al., 20066, 2008, 2017). For peptidase activity, aspartic peptidase inhibitors, such as pepstatin A (PEP) at $10 \mu \mathrm{M}$ and HIV-Pls at $100 \mu \mathrm{M}$ [indinavir (IDV), ritonavir (RTV),

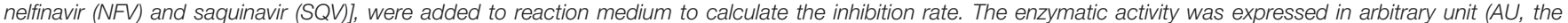

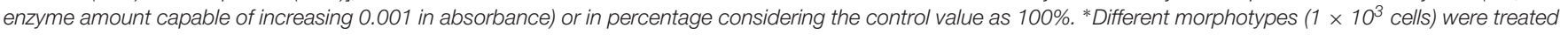
with $10 \mu \mathrm{M}$ PEPS. Sclerotic cells were treated with $10 \mu \mathrm{M}$ HIV-PIs, while the treatment of conidia were performed with $100 \mu \mathrm{M}$ HIV-PIs. After 20 h, the cells were subjected to CFU assay to measure the viable cells.

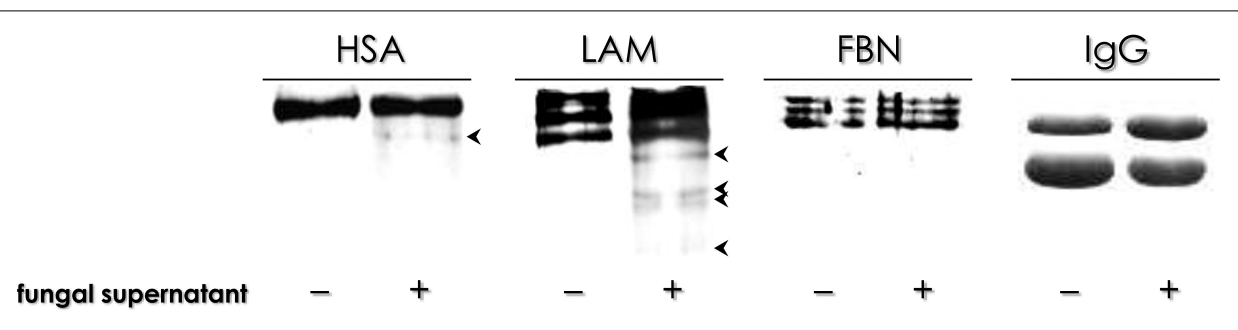

FIGURE 3 | Cleavage of soluble proteinaceous substrates by aspartic peptidase activity released by sclerotic cells. The degradation profile was analyzed by $10 \%$ SDS-PAGE and the gels were stained with Coomassie brilliant blue R-250. ( + ) Concentrated culture supernatant from sclerotic cells incubated in the presence of human serum albumin (HSA), laminin (LAM), fibronectin (FBN), and immunoglobulin $\mathrm{G}$ (lgG) for $16 \mathrm{~h}$ at $37^{\circ} \mathrm{C}$. (-) Control in which the proteinaceous substrates were supplemented only with PBS. The arrows on the right represent bands generated after substrates degradation.

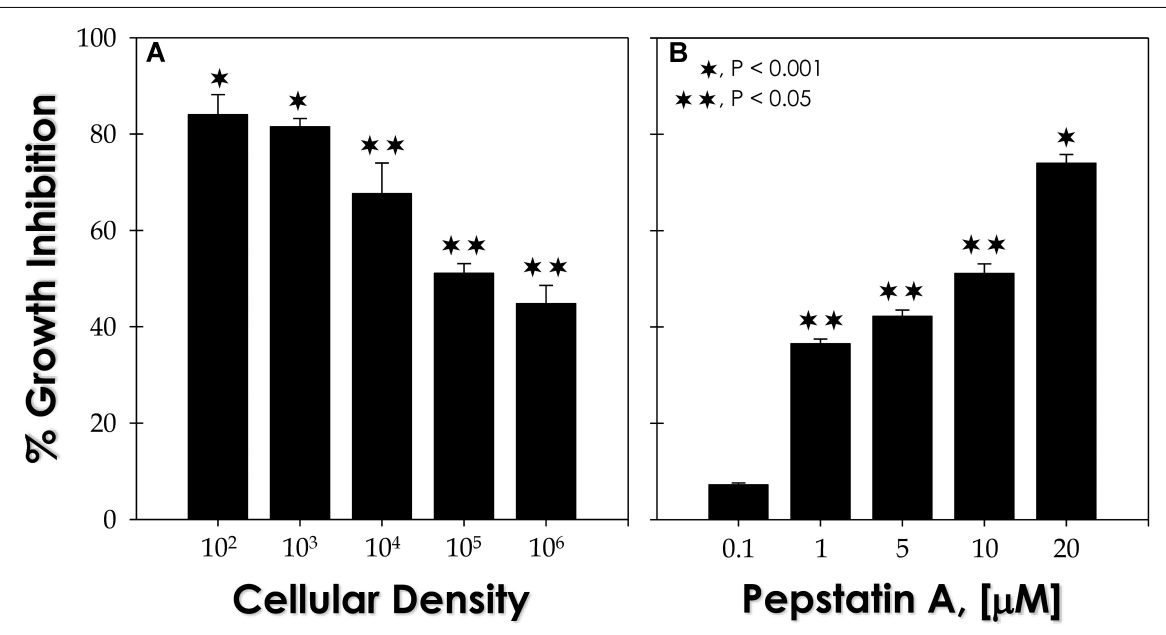

FIGURE 4 | Effects of pepstatin A on sclerotic cell viability. (A) Different fungal densities $\left(10^{2}-10^{6}\right)$ were treated with $10 \mu \mathrm{M}$ pepstatin A. (B) sclerotic cells $\left(10^{5}\right)$ were treated for $20 \mathrm{~h}$ at $37^{\circ} \mathrm{C}$ with different concentrations of pepstatin $\mathrm{A}(0.1-20 \mu \mathrm{M})$. Inhibition ratio was determined by CFU assay and data represent the mean \pm standard error of three independent experiments, which were performed in triplicate. The symbols denote the systems that had a growth rate significantly different from control ( ${ }^{*} P<0.001$ and ${ }^{*} P P<0.05$; Student's $t$-test).

profiles detected herein are in contrast to those previously observed to aspartic peptidases produced by F. pedrosoi conidia and mycelia, since them were capable of hydrolyzing FBN and IgG (Palmeira et al., 2006a,b). The ability to cleave host structural proteins was also observed in other human pathogenic fungi; for instance, A. fumigatus secretes an aspartic peptidase capable of hydrolyzing elastin, laminin and collagen in the neutropenic mice lung (Lee and Kolattukudy, 1995). In addition, C. albicans cells produce Saps with wide substrate specificity that can cleave collagen and other host matrix proteins, which contribute to fungal virulence (Naglik et al., 2003; Singh et al., 2012). Thus, the degradation of host relevant proteins by fungal aspartic peptidases allow essential pathogenesis events such as dissemination and invasion of fungal 


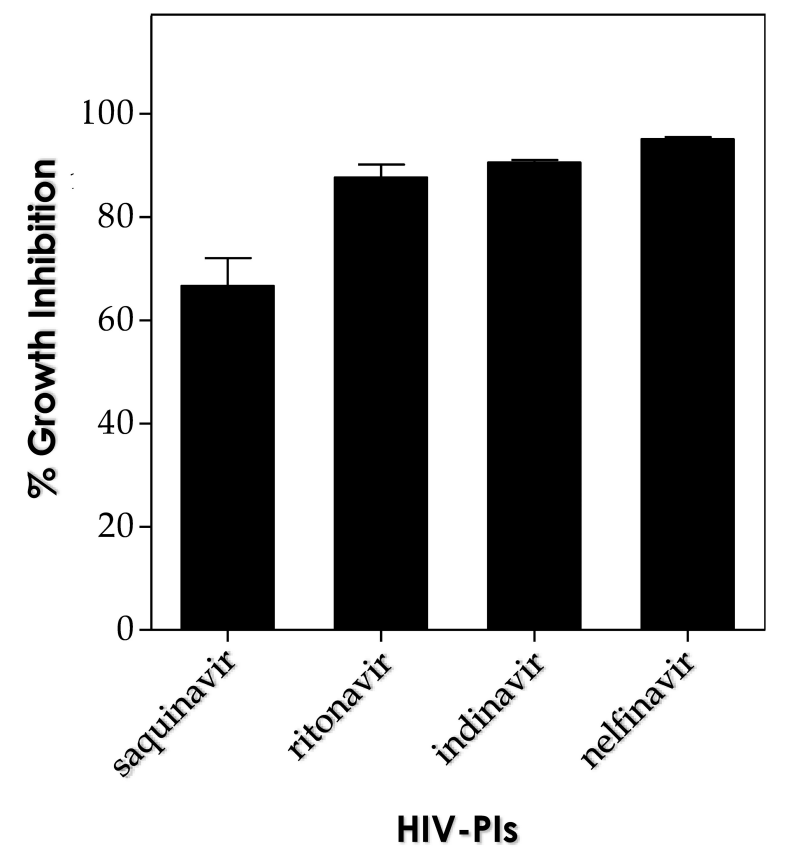

FIGURE 5 | Effects of HIV-PIs on sclerotic cell viability. Sclerotic cells $\left(10^{5}\right)$ were treated for $20 \mathrm{~h}$ at $37^{\circ} \mathrm{C}$ with $10 \mu \mathrm{M}$ of each HIV-PI (saquinavir, ritonavir, indinavir, and nelfinavir). Inhibition ratio was determined by CFU assay and data represent the mean \pm standard error of three independent experiments, which were performed in triplicate. The symbols denote the systems that had a growth rate significantly different from control $\left({ }^{*} P<0.001\right.$ and ${ }^{* *} P<0.05$; Student's $t$-test).

cells, culminating in extensive damage and/or death of the host tissue (Monod et al., 2002; Naglik et al., 2003; Singh et al., 2012).

\section{Aspartic PIs Affect the Viability of F. pedrosoi Sclerotic Cells}

Based on the efficacy of pepstatin A in reducing the viability of both conidial and mycelial forms of $F$. pedrosoi (Palmeira et al., 2006a,b, 2008), herein, it was also investigated the effect of this classical aspartic-type PI on sclerotic cells. In this context, two relevant parameters were analyzed: distinct fungal densities (Figure 4A) and different concentrations of the PI (Figure 4B). Pepstatin A at $10 \mu \mathrm{M}$ was able to considerably affect the viability of $F$. pedrosoi sclerotic cells in all the tested cellular densities (ranging from $10^{2}$ to $10^{6}$ fungal cells) (Figure 4A). In parallel, pepstatin A was also able to block the viability of sclerotic cells $\left(10^{5}\right.$ fungi) in a typically dosedependent fashion (Figure 4B). Interestingly, the HIV-PIs at $10 \mu \mathrm{M}$ were able to significantly arrest the fungal viability (>65\%), when $10^{3}$ sclerotic cells were treated for $24 \mathrm{~h}$, as follows: nelfinavir $>$ indinavir $>$ ritonavir $>$ saquinavir (Figure 5).

Supporting these findings, several studies have reported that pepstatin $\mathrm{A}$, as well as HIV-PIs have effective antifungal action in both in vitro and in vivo assays (Tsuboi et al., 1988; Borg-von Zepelin et al., 1999; Cassone et al., 1999;
Monari et al., 2005; Consolaro et al., 2006; Cenci et al., 2008; Santos et al., 2013). For instance, pepstatin A exhibited an inhibitory effect on C. albicans growth, as well as reduced the adherence of $C$. albicans to vaginal mucosa epithelial cells by approximately $55 \%$ in asymptomatic, vulvovaginal candidiasis and recurrent vulvovaginal candidiasis patients (Tsuboi et al., 1988; Consolaro et al., 2006). The same inhibitor was able to suppress the proliferation of filamentous fungi as S. schenckii (Tsuboi et al., 1988). Moreover, HIV-PIs as ritonavir and indinavir exerted a therapeutic effect in an experimental model of vaginal candidiasis, with an efficacy comparable to the antifungal drug fluconazole (Cassone et al., 1999). Tipranavir showed anti-C. neoformans effect in an experimental assay, reducing fungal burden in the liver and brain of immunocompetent and immunodepressed mice (Cenci et al., 2008).

We have previously reported that aspartic PIs have direct antifungal action against conidia and mycelia of $F$. pedrosoi (Palmeira et al., 2006b, 2008). However, the mechanisms of action of these PIs have not been completely elucidated. Recently, we showed that HIV-PIs could affect essential virulence attributes expressed by F. pedrosoi conidial cells, such as surface molecules and extracellular enzymes, involved with chromoblastomycosis development (Palmeira et al., 2017). In this line of thinking, HIV-PIs treatment reduced mannose-rich glycoconjugates and melanin molecules, and increased glucosylceramides on the conidial surface of $F$. pedrosoi. The HIV-PIs were also able to inhibit the synthesis of both ergosterol and lanosterol as well as the secretion of aspartic peptidase, esterase and phospholipase by F. pedrosoi conidial cells (Palmeira et al., 2017). In the current study, we showed that pepstatin A was able to disturb sclerotic cells viability, varying according to fungal cell number and inhibitor concentration. Surprisingly, F. pedrosoi sclerotic cells, which are highly resistant to classic antifungals drugs, were more sensitive to pepstatin A than conidia (Palmeira et al., 2006b, 2017), since $10 \mu \mathrm{M}$ of this inhibitor affected the cellular viability (inhibition of $50 \%$ of growth), even when $10^{5}$ and $10^{6}$ densities were used. In addition, the treatment of $10^{5}$ sclerotic cells with pepstatin $\mathrm{A}$ at $1 \mu \mathrm{M}$ diminished fungal proliferation by around $40 \%$. Therefore, it is important to consider that antimicrobial action is multifactorial, as it is dependent on the inoculum size and drug concentration (Gehrt et al., 1995; Palmeira et al., 2017). Moreover, antimicrobial activity can be microorganism- and/or morphology-dependent. Kasper et al. (2015) compared the clotrimazole antifungal action against C. albicans morphotypes and showed that hyphae were much more sensitive to this azole than the yeast form. In fact, studies have showed that fungal morphological changes are usually associated with intense modification of cell surface, physiology and immunology (Klein and Tebbets, 2007; Erwig and Gow, 2016).

\section{CONCLUSION}

Fonsecaea pedrosoi causes chromoblastomycosis, an occupational and neglected disease difficult to treat using the current 
available therapies. In this context, fungal biology and physiology studies contribute to a better understanding of events related to this fungus pathogenicity, revealing key molecules to be attacked by antimicrobial agents. Altogether, our data showed the presence of aspartic-type peptidase in $F$. pedrosoi sclerotic cells and implied the involvement of this enzyme in the fungal viability. Results obtained in the current and previous studies (Palmeira et al., 2006b, 2008, 2017) revealed that morphotypes of $F$. pedrosoi can exhibit aspartic peptidase activities with distinct biochemical properties, including optimum $\mathrm{pH}$, as well as different sensitivities to inhibitors, as summarized in Table 1. These findings indicate that differential expression of extracellular aspartic peptidases is directly dependent on the $F$. pedrosoi morphological stage, which can have an effect on the chromoblastomycosis pathogenesis. Studies have reported the fungal proteolytic enzymes detection may lead to a new inhibitors design to control diseases caused by these organisms (for review see, Santos et al., 2013). It is well-known that aspartic peptidases are essential targets of currently used drugs, as HIV-PIs,

\section{REFERENCES}

Alviano, C. S., Farbiarz, S. R., Travassos, L. R., Angluster, J., and de Souza, W. (1992). Effect of environmental factors on Fonsecaea pedrosoi morphogenesis with emphasis on sclerotic cells induced by propranolol. Mycopathologia 119, 17-23. doi: 10.1007/BF00492225

Alviano, D. S., Franzen, A. J., Travassos, L. R., Holandino, C., Rozental, S., Ejzemberg, R., et al. (2004). Melanin from Fonsecaea pedrosoi induces production of human antifungal antibodies and enhances the antimicrobial efficacy of phagocytes. Infect. Immun. 72, 229-237. doi: 10.1128/IAI.72.1.229237.2004

Borg-von Zepelin, M., Meyer, I., Thomssen, R., Würzner, R., Sanglard, D., Telenti, A., et al. (1999). HIV-Protease inhibitors reduce cell adherence of Candida albicans strains by inhibition of yeast secreted aspartic proteases. J. Invest. Dermatol. 113, 747-751. doi: 10.1046/j.1523-1747.1999.00747.x

Braga-Silva, L. A., Mogami, S. S., Valle, R. S., Silva-Neto, I. D., and Santos, A. L. S. (2010). Multiple effects of amprenavir against Candida albicans. FEMS Yeast Res. 10, 221-224. doi: 10.1111/j.1567-1364.2009.00595.x

Buroker-Kilgore, M., and Wang, K. K. W. (1993). A Coomassie brilliant blue G-250-based colorimetric assay for measuring activity of calpain and other proteases. Anal. Biochem. 208, 387-392. doi: 10.1006/abio.1993.1066

Cassone, A., De Bernardis, F., Torosantucci, A., Tacconelli, E., Tumbarello, M., and Cauda, R. (1999). In vitro and in vivo anticandidal activity of human immunodeficiency virus protease inhibitors. J. Infect. Dis. 180, 448-453. doi: $10.1086 / 314871$

Cenci, E., Francisci, D., Belfiori, B., Pierucci, S., Baldelli, F., Bistoni, F., et al. (2008). Tipranavir exhibits different effects on opportunistic pathogenic fungi. J. Infect. 56, 58-64. doi: 10.1016/j.jinf.2007.08.004

Consolaro, M. E. L., Gasparetto, A., Svidzinski, T. I. E., and Peralta, R. M. (2006). Effect of pepstatin A on the virulence factors of Candida albicans strains isolated from vaginal environment of patients in three different clinical conditions. Mycopathologia 162, 75-82. doi: 10.1007/s11046-006-0026-9

Dong, B., Li, D., Li, R., Chen, S. C., Liu, W., Liu, W., et al. (2014). A chitin-like component on sclerotic cells of Fonsecaea pedrosoi inhibits dectin-1-mediated murine Th17 development by masking $\beta$-glucans. PLoS One 9:e114113. doi: 10.1371/journal.pone.0114113

Douglas, T., Champagne, C., Morizot, A., Lapointe, J. M., and Saleh, M. (2015). The inflammatory caspases- 1 and -11 mediate the pathogenesis of dermatitis in sharpin-deficient mice. J. Immun. 195, 2365-2373. doi: 10.4049/jimmunol. 1500542

Erwig, L. P., and Gow, N. A. (2016). Interactions of fungal pathogens with phagocytes. Nat. Rev. Microbiol. 14, 163-176. doi: 10.1038/nrmicro.2015.21 which are raising up like attractive candidates for antifungal therapies.

\section{AUTHOR CONTRIBUTIONS}

VP, LK, and AS conceived and designed the study. VP, FG, MG, and DA performed the experiments. DA, CA, LK, and AS contributed reagents, materials and/or analysis tools. VP, FG, MG, DA, CA, LK, and AS wrote and/or revised the paper. All authors analyzed the data.

\section{FUNDING}

This work was supported by grants from the Brazilian Agencies: Conselho Nacional de Desenvolvimento Científico e Tecnológico (CNPq), Fundação Coordenação de Aperfeiçoamento de Pessoal de Nível Superior (CAPES), and Fundação de Amparo à Pesquisa no Estado do Rio de Janeiro (FAPERJ).

Gehrt, A., Peter, J., Pizzo, P., and Walsh, T. (1995). Effect of increasing inoculum sizes of pathogenic filamentous fungi on MICs of antifungal agents by broth microdilution method. J. Clin. Microbiol. 33, 1302-1307.

Granato, M. Q., Massapust, P. A., Rozental, S., Alviano, C. S., Santos, A. L. S., and Kneipp, L. F. (2015). 1,10-phenanthroline inhibits the metallopeptidase secreted by Phialophora verrucosa and modulates its growth, morphology and differentiation. Mycopathologia 179, 231-242. doi: 10.1007/s11046-0149832-7

Han, Z., Kautto, L., and Nevalainen, H. (2017). Secretion of proteases by an opportunistic fungal pathogen Scedosporium aurantiacum. PLoS One 12:e0169403. doi: 10.1371/journal.pone.0169403

Kasper, L., Miramón, P., Jablonowski, N., Wisgott, S., Wilson, D., Brunke, S., et al. (2015). Antifungal activity of clotrimazole against Candida albicans depends on carbon sources, growth phase and morphology. J. Med. Microbiol. 64, 714-723. doi: $10.1099 /$ jmm.0.000082

Klein, B. S., and Tebbets, B. (2007). Dimorphism and virulence in fungi. Curr. Opin. Microbiol. 10, 314-319. doi: 10.1016/j.mib.2007.04.002

Kneipp, L. F., Magalhães, A. S., Abi-Chacra, E. A., Souza, L. O., Alviano, C. S., Santos, A. L. S., et al. (2012). Surface phosphatase in Rhinocladiella aquaspersa: biochemical properties and its involvement with adhesion. Med. Mycol. 50, 570-578. doi: 10.3109/13693786.2011.653835

Kneipp, L. F., Palmeira, V. F., Pinheiro, A. A., Alviano, C. S., Rozental, S., Travassos, L. R., et al. (2003). Phosphatase activity on the cell wall of Fonsecaea pedrosoi. Med. Mycol. 41, 469-477. doi: 10.1080/10683160310001615399

Kneipp, L. F., Rodrigues, M. L., Holandino, C., Esteves, F. F., Souto-Padrón, T., Alviano, C. S., et al. (2004). Ectophosphatase activity in conidial forms of Fonsecaea pedroso $i$ is modulated by exogenous phosphate and influences fungal adhesion to mammalian cells. Microbiology 150, 3355-3362. doi: 10.1099/mic. 0.27405-0

Krzyściak, P. M., Pindycka-Piaszczyńska, M., and Piaszczyński, M. (2014). Chromoblastomycosis. Dermatol. Alergol. 31, 310-321. doi: 10.5114/pdia.2014. 40949

Lee, J. D., and Kolattukudy, P. E. (1995). Molecular cloning of the cDNA and gene for an elastinolytic aspartic proteinase from Aspergillus fumigatus and evidence of its secretion by the fungus during invasion of the host lung. Infect. Immun. 63, 3796-3803.

Lowry, O. H., Rosebrough, N. J., Farr, A. L., and Randall, R. J. (1951). Protein measurement with the Folin phenol reagent. J. Biol. Chem. 193, 265-275.

Madeo, F., Herker, E., Maldener, C., Wissing, S., Lächelt, S., Herlan, M., et al. (2002). A caspase-related protease regulates apoptosis in yeast. Mol. Cell. 9, 911-917. doi: 10.1016/S1097-2765(02)00501-4 
Mendoza, L., Karuppayil, S. M., and Szaniszlo, P. J. (1993). Calcium regulates in vitro dimorphism in chromoblastomycotic fungi. Mycoses 36, 157-164. doi: 10.1111/j.1439-0507.1993.tb00744.x

Monari, C., Pericolini, E., Bistoni, G., Cenci, E., Bistoni, F., and Vecchiarelli, A. (2005). Influence of indinavir on virulence and growth of Cryptococcus neoformans. J. Infect. Dis. 191, 307-311. doi: 10.1086/426828

Monod, M., Capoccia, S., Léchenne, B., Zaugg, C., Holdom, M., and Jousson, O. (2002). Secreted proteases from pathogenic fungi. Int. J. Med. Microbiol. 292, 405-419. doi: 10.1078/1438-4221-00223

Naglik, J. R., Challacombe, S. J., and Hube, B. (2003). Candida albicans secreted aspartyl proteinases in virulence and pathogenesis. Microbiol. Mol. Biol. Rev. 67, 400-428. doi: 10.1128/MMBR.67.3.400-428.2003

Oliveira, L. G., Resende, M. A., Lopes, C. F., and Cisalpino, E. O. (1973). Isolamento e identificação dos agentes da cromoblastomicose em Belo Horizonte. Rev. Soc. Bras. Med. Trop. 7, 7-10. doi: 10.1590/S0037-86821973000100002

Palmeira, V. F., Alviano, D. S., Braga-Silva, L. A., Goulart, F. R. V., Granato, M. Q., Rozental, S., et al. (2017). HIV aspartic peptidase inhibitors modulate surface molecules and enzyme activities involved with physiopathological events in Fonsecaea pedrosoi. Front. Microbiol. 8:918. doi: 10.3389/fmicb.2017. 00918

Palmeira, V. F., Kneipp, L. F., Alviano, C. S., and Santos, A. L. S. (2006a). The major chromoblastomycosis fungal pathogen, Fonsecaea pedrosoi, extracellularly releases proteolytic enzymes whose expression is modulated by culture medium composition: implications on the fungal development and cleavage of key's host structures. FEMS Immunol. Med. Microbiol. 46, 21-29. doi: 10.1111/j.1574695X.2005.00003.x

Palmeira, V. F., Kneipp, L. F., Alviano, C. S., and Santos, A. L. S. (2006b). Secretory aspartyl peptidase activity from mycelia of the human fungal pathogen Fonsecaea pedrosoi: effect of HIV aspartyl proteolytic inhibitors. Res. Microbiol. 157, 819-826. doi: 10.1016/j.resmic.2006.07.003

Palmeira, V. F., Kneipp, L. F., Rozental, S., Alviano, C. S., and Santos, A. L. S. (2008). Beneficial effects of HIV peptidase inhibitors on Fonsecaea pedrosoi: promising compounds to arrest key fungal biological processes and virulence. PLoS One 3:e3382. doi: 10.1371/journal.pone.0003382

Pozio, E., and Morales, M. A. (2005). The impact of HIV-protease inhibitors on opportunistic parasites. Trends Parasitol. 21, 58-63. doi: 10.1016/j.pt.2004. 11.003

Puri, S., Kumar, R., Chadha, S., Tati, S., Conti, H. R., Hube, B., et al. (2012). Secreted aspartic protease cleavage of Candida albicans Msb2 activates Cek1 MAPK signaling affecting biofilm formation and oropharyngeal candidiasis. PLoS One 7:e46020. doi: 10.1371/journal.pone.0046020

Queiroz-Telles, F., de Hoog, S., Santos, D. W., Salgado, C. G., Vicente, V. A., and Bonifaz, A. (2017). Chromoblastomycosis. Clin. Microbiol. Rev. 30, 233-276. doi: 10.1128/CMR.00032-16

Revankar, S. G., and Sutton, D. A. (2010). Melanized fungi in human disease. Clin. Microbiol. Rev. 23, 884-928. doi: 10.1128/CMR.00019-10

Rippon, J. W. (1988). "Chromoblastomycosis," in Medical Mycology the Pathogenic Fungi and Pathogenic Actinomycetes, ed. M. Wonsiewicz (Philadelphia, PA: WB Saunders Company), 276-296.

Santos, A. L. S. (2010). HIV aspartyl protease inhibitors as promising compounds against Candida albicans. World J. Biol. Chem. 1, 21-30. doi: 10.4331/wjbc.v1. i2.21

Santos, A. L. S., and Braga-Silva, L. A. (2013). Aspartic protease inhibitors: effective drugs against the human fungal pathogen Candida albicans. Mini Rev. Med. Chem. 13, 155-162. doi: 10.2174/1389557511307010155

Santos, A. L. S., Braga-Silva, L. A., Silva, B. A., Palmeira, V. F., Valle, R. S., Abichacra, E. A., et al. (2013). "Aspartic proteolytic inhibitors induce cellular and biochemical alterations in fungal cells," in Proteases in Health and Disease, eds S. Chakraborti and N. S. Dhalla (New York, NY: Springer), 89-119.

Santos, A. L. S., Palmeira, V. F., Rozental, S., Kneipp, L. F., Nimrichter, L., Alviano, D. S., et al. (2007). Biology and pathogenesis of Fonsecaea pedrosoi, the major etiologic agent of chromoblastomycosis. FEMS Microbiol. Rev. 31, 570-591. doi: 10.1111/j.1574-6976.2007.00077.x

Silva, B. A., Sodré, C. L., Souza-Gonçalves, A. L., Aor, A. C., Kneipp, L. F., Fonseca, B. B., et al. (2012). Proteomic analysis of the secretions of Pseudallescheria boydii, a human fungal pathogen with unknown genome. J. Proteome Res. 11, 172-188. doi: 10.1021/pr200875x

Silva, J. P., Alviano, D. S., Alviano, C. S., de Souza, W., Travassos, L. R., Diniz, J. A., et al. (2002). Comparison of Fonsecaea pedrosoi sclerotic cells obtained in vivo and in vitro: ultrastructure and antigenicity. FEMS Immunol. Med. Microbiol. 33, 63-69. doi: 10.1111/j.1574-695X.2002.tb00574.x

Silva, M. B., da Silva, J. P., Yamano, S. S. P., Salgado, U. I., Diniz, J. A., and Salgado, C. G. (2008). Development of natural culture media for rapid induction of Fonsecaea pedrosoi sclerotic cells in vitro. J. Clin. Microbiol. 46, 3839-3841. doi: 10.1128/JCM.00482-08

Singh, B., Fleury, C., Jalalvand, F., and Riesbeck, K. (2012). Human pathogens utilize host extracellular matrix proteins laminin and collagen for adhesion and invasion of the host. FEMS Microbiol. Rev. 36, 1122-1180. doi: 10.1111/j.15746976.2012.00340.x

Siqueira, I. M., de Castro, R. J. A., Leonhardt, L. C. M., Jerônimo, M. S., Soares, A. C., Raiol, T., et al. (2017). Modulation of the immune response by Fonsecaea pedrosoi morphotypes in the course of experimental chromoblastomycosis and their role on inflammatory response chronicity. PLoS Negl. Trop. Dis. 11:e005461. doi: 10.1371/journal.pntd.0005461

Tacco, B. A., Parente, J. A., Barbosa, M. S., Báo, S. N., Góes, T. S., Pereira, M., et al. (2009). Characterization of a secreted aspartyl protease of the fungal pathogen Paracoccidioides brasiliensis. Med. Mycol. 47, 845-854. doi: 10.3109/ 13693780802695512

Teixeira, M. M., Moreno, L. F., Stielow, B. J., Muszewska, A., Hainaut, M., Gonzaga, L., et al. (2017). Exploring the genomic diversity of black yeasts and relatives (Chaetothyriales, Ascomycota). Stud. Mycol. 8, 1-28. doi: 10.1016/j. simyco.2017.01.001

Tsuboi, R., Sanada, T., and Ogawa, H. (1988). Influence of culture medium pH and proteinase inhibitors on extracellular proteinase activity and cell growth of Sporothrix schenckii. J. Clin. Microbiol. 26, 1431-1433.

Valle, R. S., Ramos, L. S., Reis, V. J., Ziccardi, M., Dornelas-Ribeiro, M., Sodré, C. L., et al. (2017). Trichosporon asahii secretes a 30-kDa aspartic peptidase. Microbiol. Res. 205, 66-72. doi: 10.1016/j.micres.2017.08.015

Vicente, V. A., Weiss, V. A., Bombassaro, A., Moreno, L. F., Costa, F. F., Raittz, R. T., et al. (2017). Comparative genomics of sibling species of Fonsecaea associated with human chromoblastomycosis. Front. Microbiol. 8:1924. doi: 10.3389/fmicb.2017.01924

Vickers, I., Reeves, E. P., Kavanagh, K. A., and Doyle, S. (2007). Isolation, activity and immunological characterisation of a secreted aspartic protease, CtsD, from Aspergillus fumigatus. Protein Expr. Purif. 53, 216-224. doi: 10.1016/j.pep.2006. 12.012

Wang, L., and Lin, X. (2012). Morphogenesis in fungal pathogenicity: shape, size, and surface. PLoS Pathog. 8:1003027. doi: 10.1371/journal.ppat.1003027

Yike, I. (2011). Fungal proteases and their pathophysiological effects. Mycopathologia 171, 299-323. doi: 10.1007/s11046-010-9386-2

Conflict of Interest Statement: The authors declare that the research was conducted in the absence of any commercial or financial relationships that could be construed as a potential conflict of interest.

Copyright $\odot 2018$ Palmeira, Goulart, Granato, Alviano, Alviano, Kneipp and Santos. This is an open-access article distributed under the terms of the Creative Commons Attribution License (CC BY). The use, distribution or reproduction in other forums is permitted, provided the original author(s) and the copyright owner(s) are credited and that the original publication in this journal is cited, in accordance with accepted academic practice. No use, distribution or reproduction is permitted which does not comply with these terms. 